\title{
A New Environmentally Friendly Utilization of Energy Piles into Geotechnical Engineering in Northern China
}

\author{
Jianguo Peng, ${ }^{1}$ Qingwen Li $\mathbb{D},{ }^{1}$ and Chungho Huang $\mathbb{D}^{2}$ \\ ${ }^{1}$ Department of Civil Engineering, University of Science and Technology Beijing, Beijing 100083, China \\ ${ }^{2}$ Department of Civil Engineering, National Taipei University of Technology, Taipei 10608, Taiwan \\ Correspondence should be addressed to Qingwen Li; qingwenli@ustb.edu.cn and Chungho Huang; cdewsx.hch@gmail.com
}

Received 18 August 2021; Revised 17 October 2021; Accepted 23 October 2021; Published 23 November 2021

Academic Editor: Dong Li

Copyright (c) 2021 Jianguo Peng et al. This is an open access article distributed under the Creative Commons Attribution License, which permits unrestricted use, distribution, and reproduction in any medium, provided the original work is properly cited.

In the past 30 years, because of built-in advantages, energy saving, pollution control, and sustainability, the energy pile system has had a rapid development around the world. Many scholars did numerous researches on the parameters' optimization, heat exchange efficiency, and structure-soil response. Also, the researches of evolutional GSHP system using high temperature in deep mine and lager collection surface of tunnel lining were learned. At present, most of researchers are discussing the geothermal collection for the heating or cooling the building, and plenteous and significant research achievements have been obtained. It is a novel attempt to apply energy pile to geotechnical engineering, and good results have been achieved in engineering practice in Northern China. The area of northern China is a typical seasonal frozen region: the high temperature in summer and the cold weather and accumulated snow in winter will result in huge challenge and resource consumption of maintaince on highway tunnel, pavement, and other geotechnical engineering facilities. In this paper, taking example of using the geothermal heat exchanger to melt snow, the novel idea of using energy piles to prevent track in summer and crack in winter of pavement, and guaranteeing the safety of frost crack on tunnel lining were discussed. Also, through simulation research, we propose a buried pipe form with good heat transfer uniformity-spiral buried pipe, which has better engineering applicability. This shows us that the application of energy pile in geotechnical engineering will provide solutions to geotechnical problems, which will have a brilliant future.

\section{Introduction}

In the background of the global energy crisis, energy pile is a form of green and sustainable energy utilization, or one of the solutions to energy problems. At present, a large number of scholars have conducted scientific research on energy piles and formed a large number of research results.

1.1. The Development of Energy Pile. At present, the coal, petroleum, natural gas, and other nonrenewable energy forms are consumed rapidly, and energy crisis has become a worldwide problem. Due to the more unreasonable energy structure, this problem is more serious in China. Meanwhile, in order to realize the social sustainable development, harmonious development between the energy exploitation and environmental protection and ecological balance are required. So far, the clean energy system and energy-saving system are becoming the direction of the world's energy development strategy. And as everyone knows, comparing with the air temperature, the soil temperature is more stable the whole year, and the changing of soil temperature with depth in Beijing area is shown in Figure 1. As it can be seen, when the soil temperature is within $6 \mathrm{~m}$, the monthly temperature dispersion of soil is very large. When the soil depth exceeds $6 \mathrm{~m}$, the monthly temperature of the soil tends to be close to $18^{\circ} \mathrm{C}$. In the 1980 s, considering the stable temperature characteristic of soil, geotechnical engineers in Austria and Switzerland creatively utilized building foundations (concrete pile [1], CFG pile [2], and underground diaphragm [3-5]) placed by the heat exchanger, to process the heat exchange between fundamental components and its host soil. This new geotechnical structure, which can achieve the function of heat complementation between summer and 


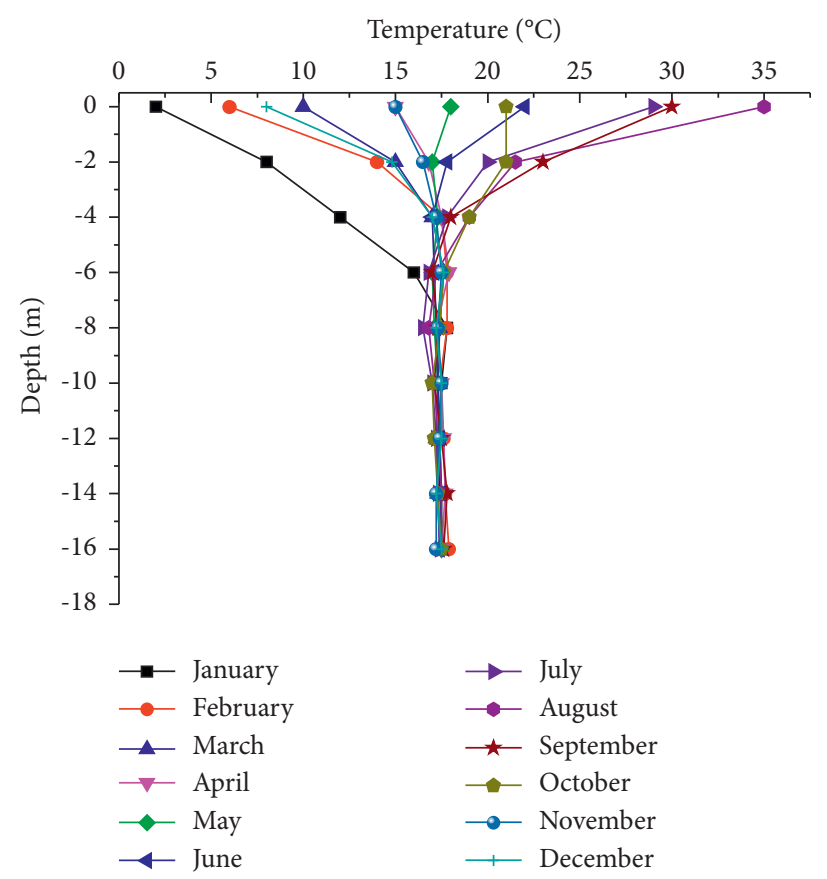

FIGURE 1: Change rule of soil temperature along with the depth.

winter, is the energy pile system. It is due to the preferable heat conduction properties of concrete and larger heat exchange surface of foundation structure that the energy pile has the better heat exchange efficiency than the traditional geothermal heat exchanger. Research results showed that the energy pile system could save more than $30 \%$ energy than air conditioning system. Meanwhile, the heat exchanger pipe is surrounded closely by pile foundation, the stability and durability could be guaranteed, and the cost of energy pile is also much lower than the traditional geothermal heat exchange system. Because of the built-in advantages, the energy pile system has achieved fast development around the world.

1.2. Research Status of Energy Pile System. In the interest of improving the heat exchange efficiency, many scholars did numerous researches on the parameters' optimization. Bozis et al. evaluated the effects of design parameters on the heat transfer efficiency and developed a methodology for comparative estimation of design alternatives of cast-in-place of energy piles [6]. Bandos et al. presented a finite cylinder-source model for simulating the energy pile heat exchangers and studied the effects of thermal storage and vertical temperature variations [7]. Moon and Choi contrastively analyzed the heating performance characteristics of the ground-source heat pump system with energy piles and energy slabs [8]. In addition, there are also many other scholars who did the parameters' optimization to improve the heat exchange efficiency [9-12]. Meanwhile, a number of scholars have already did research on the thermal performance of different coil types, and the research achievements were listed in Table 1.
As shown in Table 1, the latest studies show that spiral coil with the largest heat exchange surface of the fluid tube is the optimal type of heat exchanger cast-in-place energy pile. For the thermal efficiency analysis results, the spiral coils type has the best heating and cooling performance, accounting for near $150 \%$ thermal efficiency compared to double U type [25].

Usually, concrete energy pile systems are comprised of exchange fluid, metal pipe, concrete, and host soil, and the structural diagram is exhibited in Figure 2 [27]. It is easy to know that the thermal parameters of heat exchange medium (mainly concrete and soil) would be the important impact factor of thermal efficiency. So, many scholars begin to research the backfill material with high thermal parameters for replacing the soils with lower thermal parameters. Delaleux et al. adopted the bentonite-graphite composites as the backfill material to enhance the geothermal borehole heat exchangers performances [28]. Coccia et al. considered municipal solid waste landfills as a potential source of heat for GSHP (Ground-Source Heat Pumps) [29]. IndacoecheaVega et al. analyzed the different behaviors of different grouting materials (bentonite-based grouts and cementbased grouts) for GSHP, by contrastively proceeding the thermal conductivity, water/solid ratios, permeability, mechanical strength, and other tests [30]. Ocłoń et al. simulated the heat dissipation processes in underground power cable system situated in thermal backfill and buried in a multilayered soil [31]. Li et al. researched the heat transfer performance of the U-tube heat exchangers with different backfill materials (shape-stabilized phase change materials and crushed stone concrete) [32]. To achieve improvement of the heat exchange efficiency, scholars have discussed the parameters' optimization, types of heat exchangers cast-inplace energy piles, and the backfill material with high 
TABLE 1: Research achievements on different types of heat exchangers cast-in-place energy piles.

\begin{tabular}{|c|c|c|c|c|c|c|}
\hline Reference & U-shaped & Double U-shaped & Triple U-shaped & W-shaped & Double W-shaped & Spiral type \\
\hline Park et al. [13] & & & & & & $\star$ \\
\hline Zarrella et al. [14] & & & $\nabla$ & & & $\star$ \\
\hline Go et al. [15] & & & & & & $\star$ \\
\hline Zhang et al. [16] & & & & & & $\star$ \\
\hline Xiang et al. [17] & & & & & & $\star$ \\
\hline Go et al. [18] & & & & & & $\star$ \\
\hline Lee et al. [19] & & & & & & $\star$ \\
\hline Yoon et al. [20] & & & & $\diamond$ & & $\star$ \\
\hline Wang et al. [21] & & & & & & $\star$ \\
\hline Wang et al. [22] & & & & & & $\star$ \\
\hline Park et al. [23] & & & & & & $\star$ \\
\hline Zhao et al. [24] & - & & & $\diamond$ & & $\star$ \\
\hline Luo et al. [25] & & $\boldsymbol{\Delta}$ & $\boldsymbol{\nabla}$ & & $\bullet$ & $\star$ \\
\hline Zarrella et al. [26] & $\mathbf{0}$ & & & & & \\
\hline
\end{tabular}

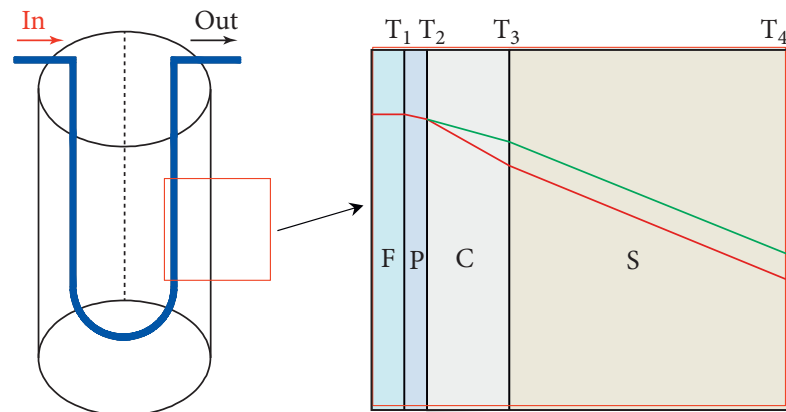

FIGURE 2: Energy pile with $U$ tube and its heat transfer medium diagram.

thermal parameters. A series of mature and applicable achievements were obtained.

For the energy pile, it is not only a heat-exchanging system, but also a foundation structure, so it should meet the double requirement of heat exchanging and supporting. The research on different mechanical property of pile under the cyclic action of cooling and heating is necessary. Suryatriyastuti et al. studied the the temperature-induced mechanical behavior of energy pile foundations [33]. Park et al. evaluated the thermal response and performance of precasthigh strength concrete energy pile by taking results of field experiments and numerical simulation [34]. Besides, there are also abundant researches on structural response between pile and soil [35-44]. For the group of energy piles, scholars and professionals in many countries also did the corresponding research on the multiple interaction [45-47] and mechanical response [48-51]. By studying the above references, plenteous and significant achievements on the research of energy pile system were realized, and it has been widely used in green energy-saving buildings in China, European countries, Canada, Japan, and other countries.

\section{Evolutional GSHP System Use with Geotechnical Engineering Structure}

2.1. Geothermal Heat Extraction from Mines. With the development of mining depth, the high temperature problem is becoming more and more serious. In China, the temperature in working faces at more than $700 \mathrm{~m}$ mining depth are mostly larger than $35^{\circ} \mathrm{C}$, the highest temperature is near $50^{\circ} \mathrm{C}$, and the typical rock temperatures of deep mine are listed in Table 2.

It is easy to know that the working environment under high temperature not only has an effect on the mechanical property of host rock but also inflicts harm to the body health of worker. The high temperature environment would reduce their ability of attention and reaction; sometimes, these effects may lead to real accidents. According to the surveyed data by the former Soviet Union and Germany, the labor productivity will decline by $6 \% \sim 8 \%$ when the working temperature is $1^{\circ} \mathrm{C}$ out of limit [52]. Based on the surveyed data of 7 mines in Hokkaido, Japan, the results show that the accident rate at working face under $37^{\circ} \mathrm{C}$ is 2.13 times that under $30^{\circ} \mathrm{C}$ [53]. So it is very important to research the technique of high temperature control and cooling. And many scholars have done some research on how to cool deep mine heat. $\mathrm{He}$ et al. adopted a high temperature exchange machinery system (HEMS) to cool the high temperature and control heat hazard in deep coal mines [54]. Plessis et al. analyzed the variable speed drives for cost-effective energy savings in South African mine cooling systems and found that an annual cost saving of USD 6,938,148 and $\mathrm{CO}_{2}$ emissions reduction of $132 \mathrm{M}$ ton are possible [55], and they further researched the development and integrated simulation of a variable water flow energy-saving strategy for deep mine cooling systems at 2015 [56]. Apel et al. simulated the effects of thermal insulating shotcrete on the energy consumption of ventilation and cooling systems at deep underground mines [57]. Chen et al. proposed a split-type vapor compression refrigerator for heat hazard control in deep mines [58]. With the developing and improving of the studying about heat hazard in deep mines, some people have realized that the high temperature is also an energy source and also can be utilized. Guo et al. used the HEMS technique to control the heat harm in Jiahe coal mine (Hunan province, China) and extracted the deep geothermal energy to replace the ground fired boiler for heating [59]. GhoreishiMadiseh and Abbasy did the numerical and experimental study of geothermal heat extraction from backfilled mine 
TABle 2: Rock temperatures of deep mine in Northern China.

\begin{tabular}{|c|c|c|c|}
\hline Mines & Geographical location & Measuring depth $(\mathrm{m})$ & Rock temperature $\left({ }^{\circ} \mathrm{C}\right)$ \\
\hline Dataigou iron mine & Liaoning province & 1250 & $41.4 \sim 43.0$ \\
\hline Linglong Gold mine & Shandong province & 1095 & $42.0 \sim 44.0$ \\
\hline Lingnan Gold mine & Shandong province & 975 & 40.0 \\
\hline Xiadian Gold mine & Shandong province & 850 & 35.2 \\
\hline Sanshandao Gold mine & Shandong province & 825 & 38.5 \\
\hline Xincheng Gold mine & Shandong province & 760 & $37.0 \sim 38.0$ \\
\hline
\end{tabular}

stopes [60]. Furthermore, Ramos et al. discussed the feasibility of using abandoned mines for geothermal heat recovery [61]. Guo et al. present a geothermal recycling system for parallel mine, where the collected heat can be used to supply heat for buildings and domestic hot water [62]. The schematic diagram of geothermal heat extraction from mines is shown in Figure 3. Driven by the circulation system, the heat exchange fluid circulates inside the mine, fully contacts the surrounding high temperature rock and soil, and extracts the heat for ground buildings.

\subsection{Geothermal Heat Collection from Tunnel (Energy Tunnel).} To extract the heat from mine is utilization of deeper geothermal resource, and for the shallow geothermal resource utilization, the researchers have noticed the tunnel. Mimouni and Laloui estimated the geothermal potential of heat exchanger anchors on a cut-and-cover tunnel, and the numerical simulation results showed that the extractable heat from the ground through the anchors ranges from 0.4 to $0.8 \mathrm{GWh}$ per year and per kilometer of tunnel [63]. Barla et al. discussed the application of energy tunnels to an urban environment and investigated the possibility of thermal activation of a new section underground construction of the Metro Torino line 1 (Italy) to heat and cool adjacent buildings [64]. Lee et al. introduced development of energy textile to use geothermal energy in tunnels and conducted a test bed of six pilot energy textile modules with various configurations in an abandoned railroad tunnel in South Korea [65]. Buhmann et al. summarized the German experience with renewable energy concepts in tunnel projects [66]. López et al. evaluated energy consumption and sustainability of road tunnels [67]. The typical tunnel lining was equipped as ground heat exchanger as shown in Figure 4. Through the pipeline buried on the lining surface, the heat on the tunnel surface is collected to the heat collecting pipe to realize the efficient utilization of geothermal energy.

\section{Geothermal Energy Resources in Northern China}

China has rich geothermal resources accounting for $8 \%$ of total global geothermal energy reserve [68]. The distribution of geothermal resources in China was consulted as shown in Figure 5.

As shown in Figure 5, the main distribution of geothermal resources is in Northern China, including the Songliao Basin, Erlian Basin, North Basin, Ordos Basin,
Qaidam Basin, and Tarim Basin. The shallow geothermal resource, which can be utilized by the energy piles, is also very abundant. According to the shallow depth data (within $200 \mathrm{~m}$ ) provided by China Geological Survey, an evaluation on the shallow geothermal resources of 16 provinces in Northern China was performed [70, 71]. The shallow geothermal energy data in Northern China are listed in Table 3. It is easy to learn that the shallow geothermal resources in Northern China (16 calculated provinces) are about $31.32 \times 10^{12} \mathrm{kWh}$, equal to 3752 million tons of standard coal. Considering the available shallow geothermal resource, the value is more than $1.17 \times 10^{12} \mathrm{kWh}$, equal to 145 million tons of standard coal.

\section{Energy Piles Utilized in Geotechnical Engineering}

When solving geotechnical engineering problems, the traditional engineering technical measures have the characteristics of high pollution and high energy consumption. Under the background of carbon peak, carbon neutralization and green industrial revolution, huge green and clean geothermal energy reserves, and the great development of energy pile technology in the world, energy pile has been vigorously promoted and applied in Northern China. Combined with the geographical characteristics of seasonal freezing area in Northern China, specific application forms have been developed, such as snow melting and deicing, realization of wide temperature range of asphalt concrete pavement, and prevention and control of frost heave and frost crack of tunnel inlet and outlet lining.

In the northern China, there is a huge distance of air temperature between winter and summer; the daily variation of four seasons' temperature in Beijing area is shown in Figure 6. According to the Köppen classification, the climate types in Northern China are mainly Dwb (cold dry winter, warm summer) and Bsk (arid steppe, cold). In the past 30 years, the climate types in North China have changed significantly [72-74], which is of great value in the utilization of geothermal energy.

As shown in Figure 6, Beijing area is a typical seasonal frozen region in China, where the lowest air temperature in winter is about $-15^{\circ} \mathrm{C}$, the highest temperature in summer can reach more than $35^{\circ} \mathrm{C}$, and the cold weather and accumulated snow in winter and the high temperature in summer will result in huge challenge and resource consumption of maintaince on highway tunnels, pavements, and other geotechnical engineering facilities. 


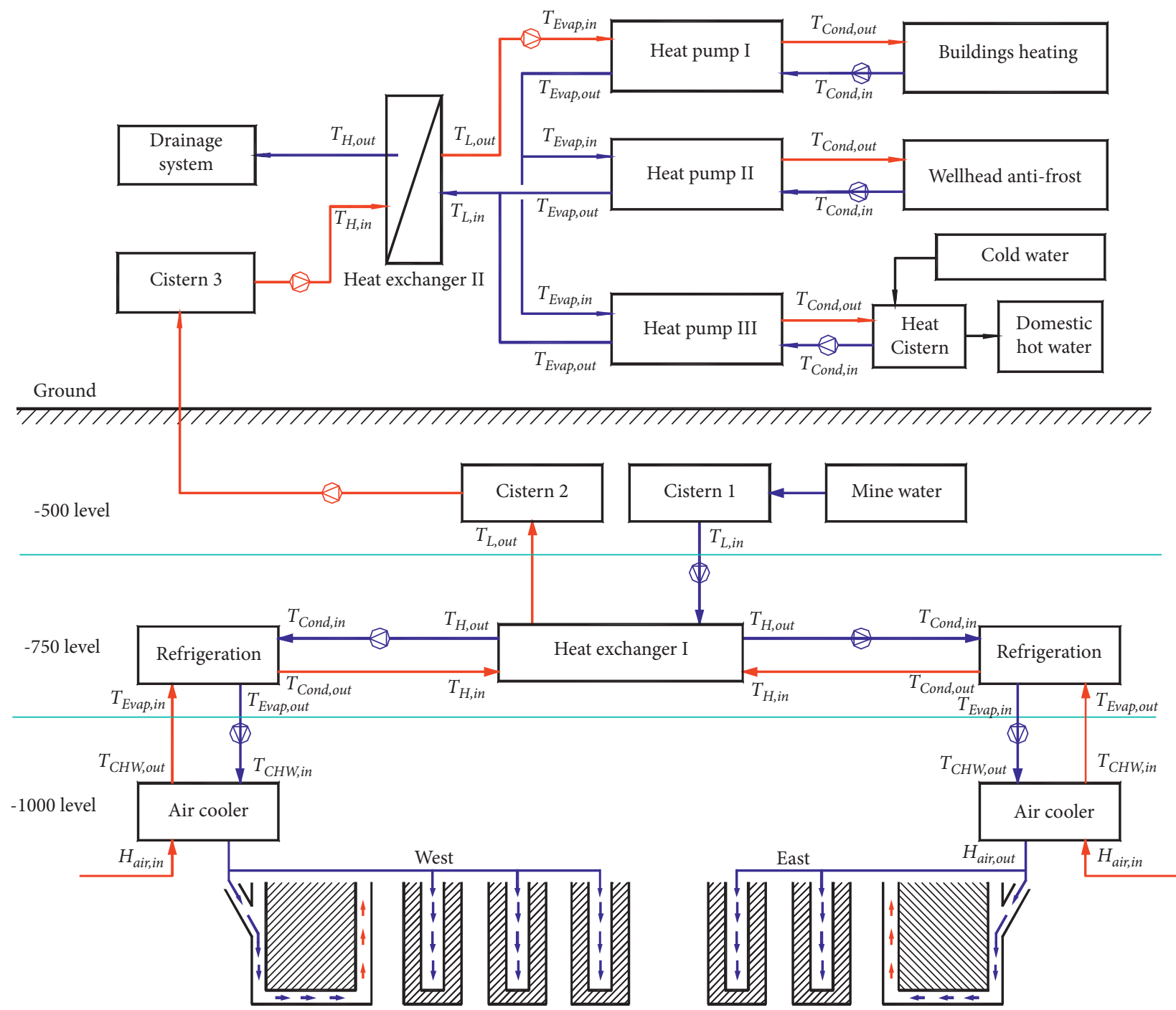

FIgURE 3: The schematic diagram of geothermal heat extraction in the Zhang Shuang-lou Mine [62].

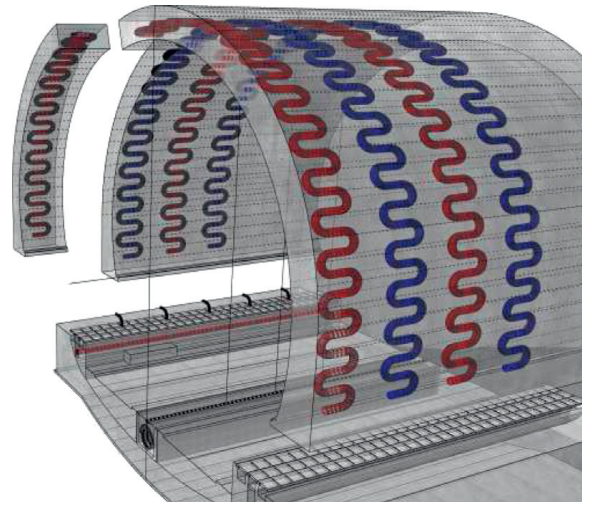

FIgURE 4: Schematic representation of a segmental tunnel lining equipped as heat exchanger [64].

4.1. GSHPSystem Used for Melting Snow. In Northern China, the continuous low temperature may bring about the accumulated snow for several months; usually, the pavement is icy. This accumulated snow and ice would cause the huge hidden danger for the motion of the vehicle safety. Now, for the snow and ice melting, numerous methods were proposed by scholars. All the common methods could be classified as chemical snow melting method and physical snow melting method. The chemical method uses salt-storage aggregates [75], sodium chloride [76], and other chemicals to melt the snow and ice on pavement; however, chemicals usually have a negative impact on the surround environment, and it is corrosive to vehicles and roadside structures. The physical method is utilization of natural heat or generated heat by employing a conductive asphalt solar collector [77], carbon fiber grille [78], copper plates [79], heating films [80], and electric heating pipes [81, 82], to remove the accumulated snow and ice. Although the above introduced methods could melt snow effectively, the low efficiency or huge electric energy consumption always restricts their wide application. With the development of GSHP system, some scholars have begun to study its practicability in melting of accumulated snow on pavement. Pan et al. summarized a review on hydronic asphalt pavement for energy harvesting and snow melting [83]. Yildirim and Hepbasli analyzed the 


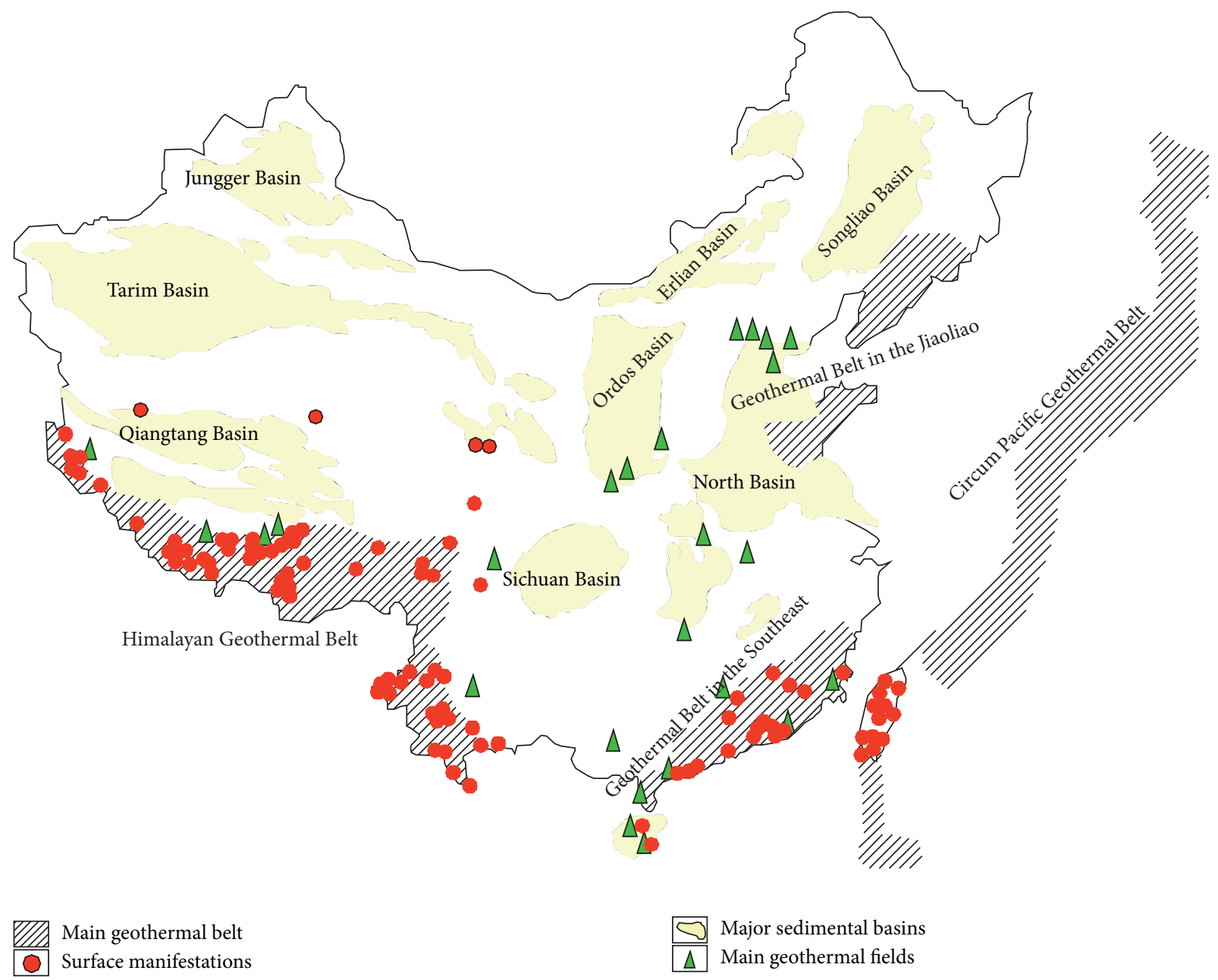

FIgURE 5: The geothermal resources distribution in China [69].

TABLE 3: Evaluation of the shallow geothermal resources in Northern China [71].

\begin{tabular}{|c|c|c|c|c|c|c|}
\hline \multirow{2}{*}{ No. } & \multirow{2}{*}{ Province or city } & \multicolumn{2}{|c|}{ Total resource capacity } & \multicolumn{2}{|c|}{ Available resource capacity } & \multirow{2}{*}{$\begin{array}{c}\text { Benefit } \\
\text { Reduction of } \mathrm{CO}_{2}(\mathrm{Mt})\end{array}$} \\
\hline & & $\times 10^{12} \mathrm{kWh}$ & Standard coal (Mt) & $\times 10^{9} \mathrm{kWh}$ & Standard coal (Mt) & \\
\hline 1 & Heilongjiang & 3.31 & 407 & 124 & 15 & 0.40 \\
\hline 2 & Jilin & 1.84 & 226 & 69.1 & 9 & 0.22 \\
\hline 3 & Liaoning & 3.30 & 406 & 124 & 15 & 0.40 \\
\hline 4 & Hebei & 2.32 & 285 & 87.0 & 11 & 0.28 \\
\hline 5 & Beijing & 3.01 & 270 & 113 & 14 & 0.36 \\
\hline 6 & Tianjin & 1.75 & 215 & 65.6 & 8 & 0.21 \\
\hline 7 & Inner Mongolia & 1.80 & 221 & 67.7 & 8 & 0.22 \\
\hline 8 & Shanxi & 1.67 & 205 & 62.7 & 8 & 0.20 \\
\hline 9 & Shandong & 3.47 & 427 & 130 & 16 & 0.42 \\
\hline 10 & Henan & 3.45 & 424 & 129 & 16 & 0.42 \\
\hline 11 & Shanxi & 2.24 & 276 & 84.2 & 10 & 0.27 \\
\hline 12 & Ningxia & 0.974 & 120 & 36.5 & 4 & 0.12 \\
\hline 13 & Gansu & 1.21 & 149 & 45.5 & 6 & 0.15 \\
\hline 14 & Qinghai & 0.16 & 20 & 6.00 & 1 & 0.02 \\
\hline 15 & Xinjiang & 0.486 & 60 & 18.2 & 2 & 0.06 \\
\hline 16 & Tibet & 0.330 & 41 & 12.4 & 2 & 0.04 \\
\hline \multicolumn{2}{|c|}{ Total in Northern China } & 31.32 & 3752 & 1174.9 & 145 & 3.79 \\
\hline
\end{tabular}




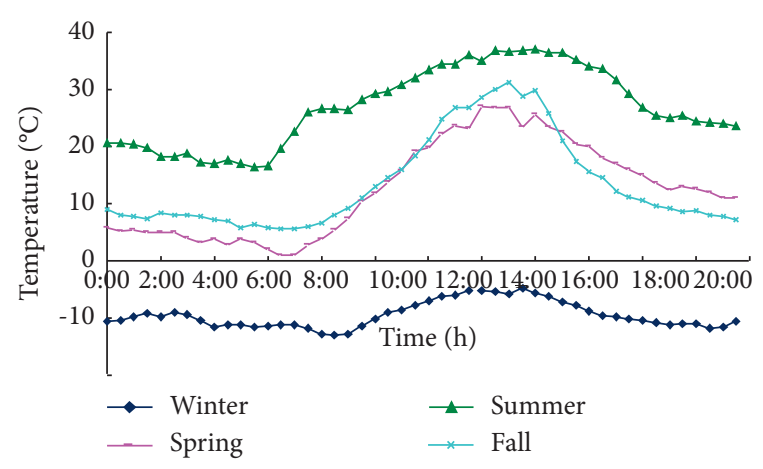

Figure 6: Daily variation of four seasons' temperature in Beijing area.

performance of snow melting using a GSHP system [84]. Xu and Tan simulated the pavement snow melting systems utilizing low temperature heating fluids [85]. Han and $\mathrm{Yu}$ discussed the feasibility of geothermal heat exchanger pilebased bridge deck snow melting system [86]. Wang et al. performed the thermal analysis and optimization of an ice and snow melting system using geothermal energy by superlong flexible heat pipes [87].

4.2. Guaranteeing Pavement Safety Using Energy Piles. The pavement asphalt is one of temperature sensitive materials; it will have different mechanical properties under different outer circumstance temperatures. In some regions of Northern China, due to the heat-trapping property of asphalt, the surface temperature of pavement can reach $50^{\circ} \mathrm{C}$ in summer, but this value is only $-15^{\circ} \mathrm{C}$ in winter, and the temperature difference can reach $65^{\circ} \mathrm{C}$. Researches show that dynamic modulus will reduce from $12,000 \mathrm{MPa}$ to $100 \mathrm{MPa}$ under 0.01 frequency when the environment temperature rises from $-20^{\circ} \mathrm{C}$ to $54^{\circ} \mathrm{C}$ [88], as it can be seen in Figure 7 . Hence, the contradictory issues between track in summer and crack of pavement asphalt in winter are especially serious, as shown in Figures 8 and 9, respectively.

For the purpose of dealing with the above contradictory problems, the traditional solving method is striving to develop wide temperature range asphalt material [89-92]. Although many efforts have been done, most of researches could solve the low temperature crack [93] and high temperature track [94] very well separately. It is really difficult to solve these contradictory problems uniformly. In the face of this bottleneck, the other new approach could be explored. Proceeding from that, taking example of GSHP system used for melting snow, and comprehensively considering mature and practical technique and higher thermal efficiency of energy pile and rich shallow geothermal resource in Northern China area, it is possible to implement the energy pile into roadbed structure, to solve the seasonal temperature-induced contradictory problems on pavement. The working schematic diagram of energy piles roadbed is shown in Figure 10. The temperature of the circulating liquid is increased through the vertical solenoid and then flows through the horizontal buried pipe to heat the road surface, so as to improve the road temperature and melt the snow in the road area.

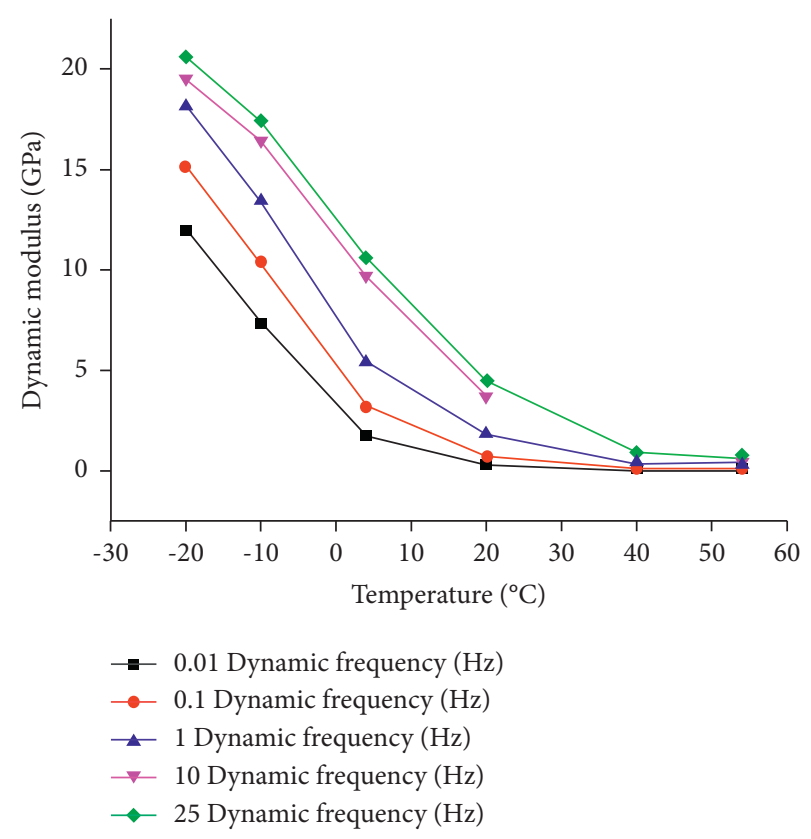

Figure 7: Relationships between dynamic modulus and temperature under different frequencies [85].

As shown in Figure 10, by using piles in composite road foundation, the spiral coil with the largest heat exchange surface of the fluid tube is the selected type of heat exchanger cast-in-place energy piles. And taking advantage of good thermal performance and protective layer, the pipes with multi- $U$ type were installed in concrete roadbed. The dynamic modulus of asphalt material (as shown in Figure 7) has strong correlation with the environment temperature. And the soil temperature changing law (as shown in Figure 1) indicates that the soil temperature is stable at $18^{\circ} \mathrm{C}$ under more than $6 \mathrm{~m}$ depth. With utilizing the existing piles in roadbed, the energy pile system can be installed. If the energy piles system can change $30 \%$ of temperature differences, the pavement temperature will be about $40^{\circ} \mathrm{C}$ in summer and about $-2^{\circ} \mathrm{C}$ in winter. So, under this situation, most of the existing asphalt material can meet the temperature requirements, which also means the energy pile system could solve the contradictory problem of track in summer and crack in winter on pavement.

\subsection{Preventing Frost Crack Induced by Seepage Using Energy} Piles. Such as Chengde area in Northern China, there is rich underground water in mountains, the low temperature will freeze the underground water around open surface in winter, and the lining at exit and entrance of tunnel will suffer the frost heave force continually with supply underground water. As time passes, a lot of tunnels' linings at position of exit and entrance are facing the water leakage problems. The more serious problem is that the leaked water will be freezing as the ice rapidly. A big block of ice will be hung and accumulated at the roof and road surface, respectively (as shown in Figure 11). It will be a huge potential safety hazard for traffic safety. 


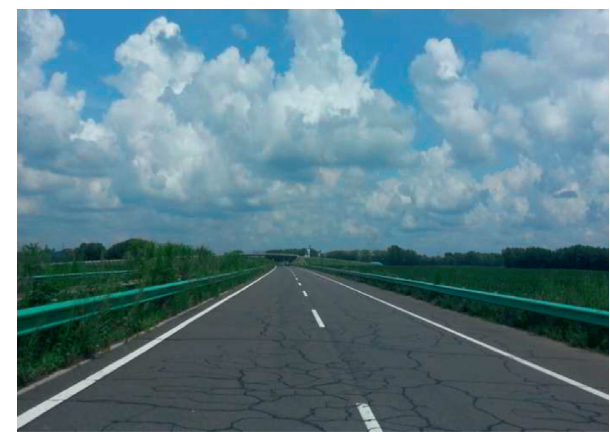

FIgURe 8: Pavement crack in winter.

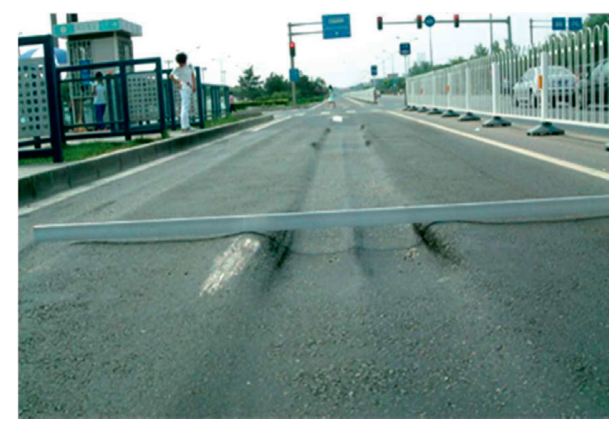

FIgURe 9: Pavement track in summer.

Also, using the energy piles system to collect the heat from ground for heating the lining at both ends of tunnel, the frost heave phenomenon could be avoided. And then, the hanging and accumulating ice problem will be nonexistent. This system is the reverse utilization of energy tunnel, as shown in Figure 4: the heat collection structures are changed as the heat sink structure, and the schematic diagram is shown in Figure 12.

As shown in Figure 12, by using piles in tunnel lining, the spiral coil with the largest heat exchange surface of the fluid tube is the selected type of heat exchanger cast-in-place energy piles. And taking advantage of good thermal performance, the pipes with multi-U type were installed in concrete tunnel lining; also these multi-U type pipes could replace the steel in concrete tunnel lining. The soil temperature changing law (as shown in Figure 1) indicates that the soil temperature is stable at $18^{\circ} \mathrm{C}$ under more than $6 \mathrm{~m}$ depth. If the energy piles system can keep temperature above $0^{\circ} \mathrm{C}$, the problem of frost crack induced by seepage could be avoided.

4.4. Simulation Study on Buried Pipe Form. Usually, we adopt the form of several shaped buried pipes. However, in engineering practice, we found that the heat transfer uniformity of several shaped buried pipes is poor. When the pipe spacing is large, the temperature at the center between pipes is low. When it is applied to road snow melting and deicing, it will cause uneven melting of ice and snow; when the pipe spacing is small, the temperature near
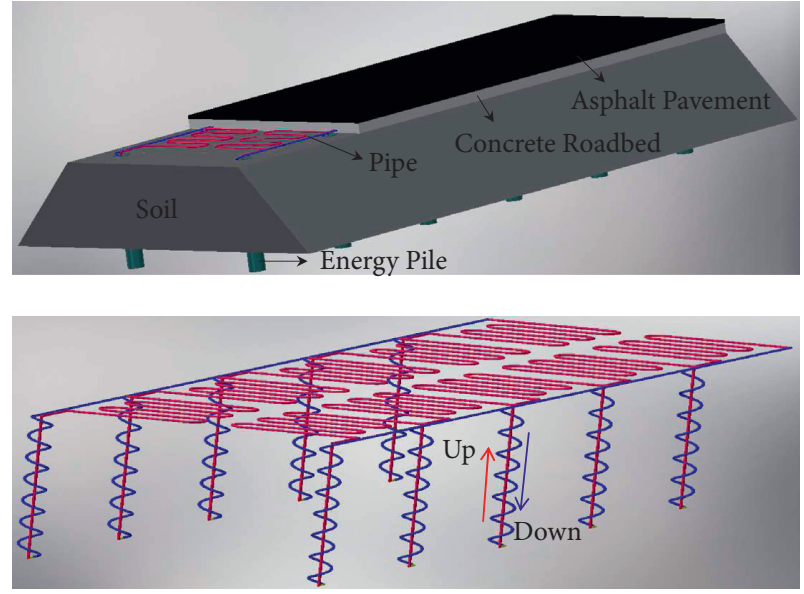

FIgURE 10: The working schematic diagram of energy piles roadbed and laying pipes.

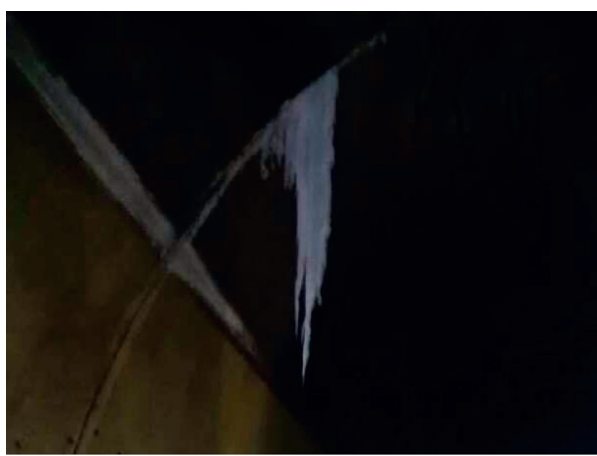

(a)

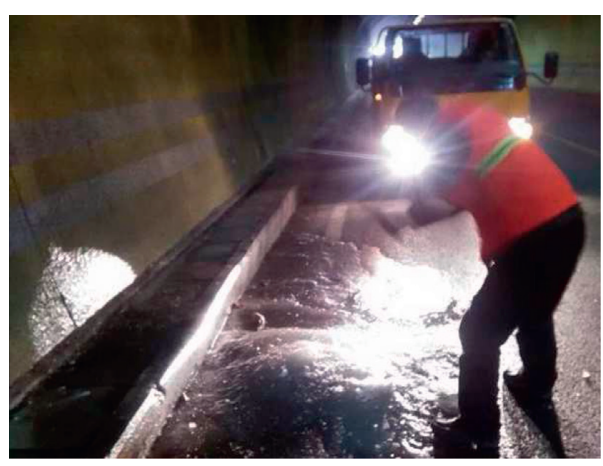

(b)

FIGURE 11: The hanging and accumulating ice at the roof and road surface.

the buried pipe is high, which wastes resources. After considering the above factors, the spiral buried pipe and zigzag buried pipe form are designed to discuss better heat transfer effect. The solid heat transfer and pipe heat transfer module in COMSOL is used for simulation, and the results are shown in Figure 13. The results show that the spiral buried pipe has better heat transfer uniformity and better engineering applicability compared with the zigzag buried pipe. 


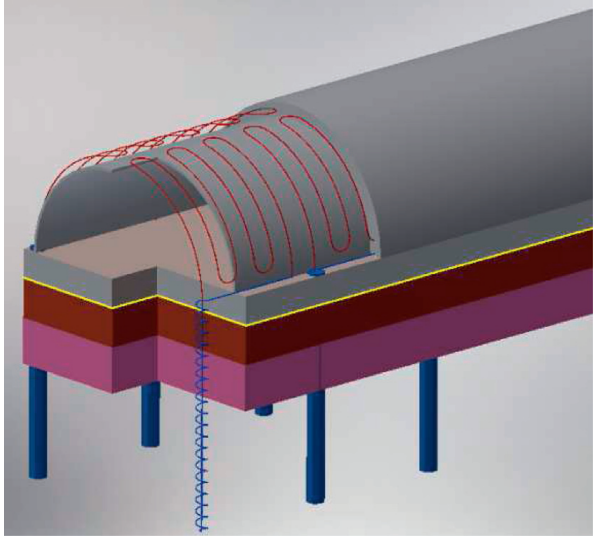

(a)

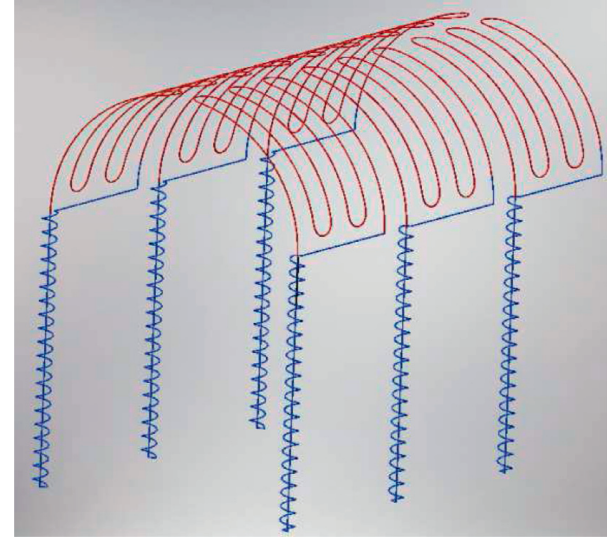

(b)

FIGURE 12: The working schematic diagram of energy piles tunnel lining and laying pipes.

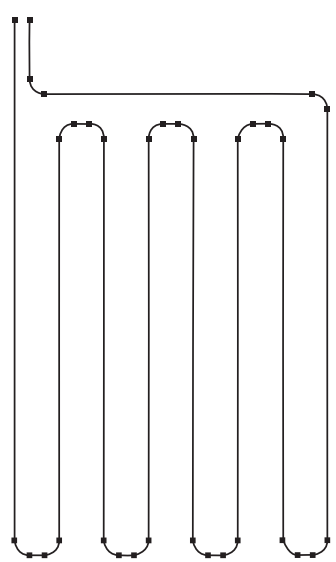

(a)

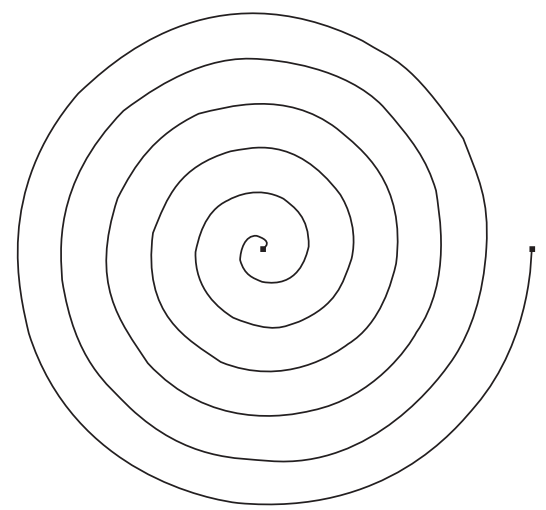

(c)

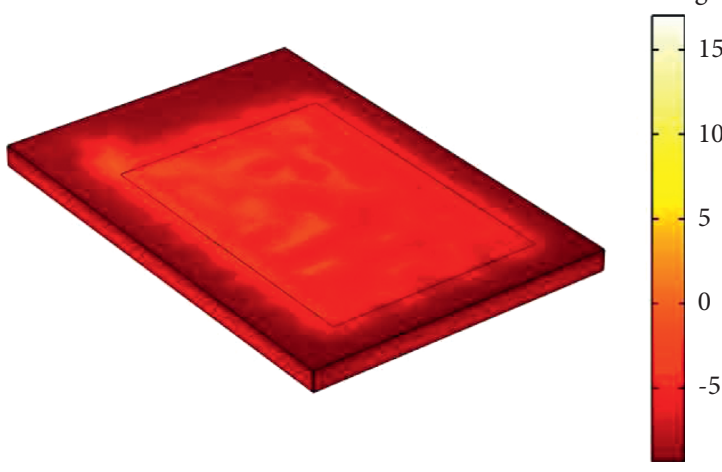

(b)
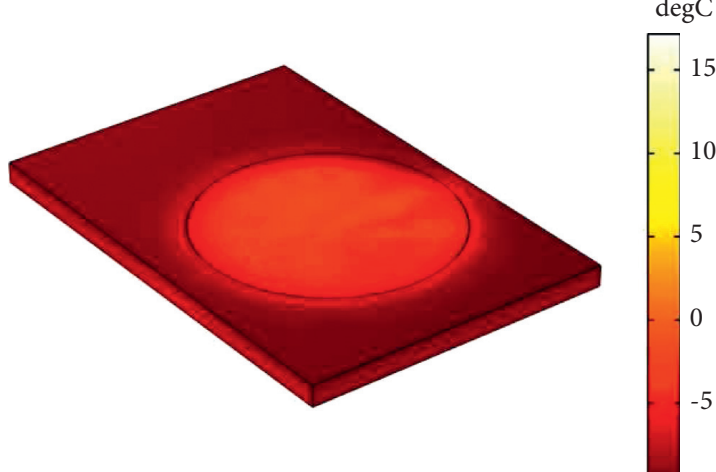

(d)

Figure 13: Pavement temperature distribution after 10 days of operation with buried depth of $0.5 \mathrm{~m}$. (a) Zigzag buried pipe. (b) Heat exchange of zigzag buried pipe. (c) Spiral buried pipe. (d) Heat exchange of spiral buried pipe.

\section{Conclusion and Discussion}

In the recent 30 years, a large number of scholars have conducted extensive and in-depth research on the energy pile system. Through experimental research and numerical simulation, from parameter optimization and heat transfer efficiency to structure-soil response, they continuously promote the application of energy pile system from theory to engineering practice.

With the continuous development of ground-source heat pump system, researchers introduced it into geotechnical engineering from the field of building energy 
conservation and applied it to deep mine geothermal collection and tunnel lining surface heat collection, which expanded the utilization forms of ground-source heat pump system.

The area of Northern China has abundant shallow geothermal resources. As a typical seasonal frozen soil area, it is high in summer and cold in winter. The application of ground-source heat pump system in geotechnical engineering has obvious popularization and application value. Hence, taking example of using the geothermal heat exchanger to melt snow, the novel idea of using energy piles to prevent track in summer and crack in winter of pavement and guarantee the safety of frost crack on tunnel lining was discussed, to develop implementation of the energy pile into geotechnical engineering. And through the simulation study, compared with the zigzag buried pipe, it is found that the arrangement form of spiral buried pipe has better heat transfer uniformity and engineering applicability.

\section{Conflicts of Interest}

The authors declare that they have no conflicts of interest.

\section{Acknowledgments}

This work was supported by the Opening Funds of State Key Laboratory of Building Safety and Built Environment (no. BSBE2015-06) and Joint Research Program between University of Science and Technology Beijing and National Taipei University of Technology (no. TW201703).

\section{References}

[1] S. Park, D. Lee, H.-J. Choi, K. Jung, and H. Choi, "Relative constructability and thermal performance of cast-in-place concrete energy pile: coil-type GHEX (ground heat exchanger)," Energy, vol. 81, pp. 56-66, 2015.

[2] S. You, X. Cheng, H. Guo, and Z. Yao, "Experimental study on structural response of CFG energy piles," Applied Thermal Engineering, vol. 96, pp. 640-651, 2016.

[3] C. Xia, M. Sun, G. Zhang, S. Xiao, and Y. Zou, "Experimental study on geothermal heat exchangers buried in diaphragm walls," Energy and Buildings, vol. 52, pp. 50-55, 2012.

[4] M. Sun, C. Xia, and G. Zhang, "Heat transfer model and design method for geothermal heat exchange tubes in diaphragm walls," Energy and Buildings, vol. 61, pp. 250-259, 2013.

[5] P. J. Bourne-Webb, T. M. Bodas Freitas, and R. A. da Costa Gonçalves, "Thermal and mechanical aspects of the response of embedded retaining walls used as shallow geothermal heat exchangers," Energy and Buildings, vol. 125, pp. 130-141, 2016.

[6] D. Bozis, K. Papakostas, and N. Kyriakis, "On the evaluation of design parameters effects on the heat transfer efficiency of energy piles," Energy and Buildings, vol. 43, no. 4, pp. 1020-1029, 2011.

[7] T. V. Bandos, Á. Campos-Celador, L. M. López-González, and J. M. Sala-Lizarraga, "Finite cylinder-source model for energy pile heat exchangers: effects of thermal storage and vertical temperature variations," Energy, vol. 78, pp. 639648, 2014.
[8] C.-E. Moon and J. M. Choi, "Heating performance characteristics of the ground source heat pump system with energypiles and energy-slabs," Energy, vol. 81, pp. 27-32, 2015.

[9] F. Cecinato and F. A. Loveridge, "Influences on the thermal efficiency of energy piles," Energy, vol. 82, pp. 1021-1033, 2015.

[10] A. A. Mehrizi, S. Porkhial, B. Bezyan, and H. Lotfizadeh, "Energy pile foundation simulation for different configurations of ground source heat exchanger," International Communications in Heat and Mass Transfer, vol. 70, pp. 105-114, 2016.

[11] R. Caulk, E. Ghazanfari, and J. S. McCartney, "Parameterization of a calibrated geothermal energy pile model," Geomechanics for Energy and the Environment, vol. 5, pp. 1-15, 2016.

[12] J. Fadejev, R. Simson, J. Kurnitski, and F. Haghighat, "A review on energy piles design, sizing and modelling," Energy, vol. 122, pp. 390-407, 2017.

[13] S. Park, S.-R. Lee, H. Park, S. Yoon, and J. Chung, "Characteristics of an analytical solution for a spiral coil type ground heat exchanger," Computers and Geotechnics, vol. 49, pp. 18-24, 2013.

[14] A. Zarrella, M. De Carli, and A. Galgaro, "Thermal performance of two types of energy foundation pile: helical pipe and triple U-tube," Applied Thermal Engineering, vol. 61, no. 2, pp. 301-310, 2013.

[15] G.-H. Go, S.-R. Lee, S. Yoon, and H.-b. Kang, "Design of spiral coil PHC energy pile considering effective borehole thermal resistance and groundwater advection effects," Applied Energy, vol. 125, pp. 165-178, 2014.

[16] W. Zhang, H. Yang, L. Lu, P. Cui, and Z. Fang, "The research on ring-coil heat transfer models of pile foundation ground heat exchangers in the case of groundwater seepage," Energy and Buildings, vol. 71, pp. 115-128, 2014.

[17] Y. Xiang, H. Su, W. Gou et al., "A new practical numerical model for the energy pile with spiral coils," International Journal of Heat and Mass Transfer, vol. 91, pp. 777-784, 2015.

[18] G.-H. Go, S.-R. Lee, H.-B. Kang, S. Yoon, and M.-J. Kim, “A novel hybrid design algorithm for spiral coil energy piles that considers groundwater advection," Applied Thermal Engineering, vol. 78, pp. 196-208, 2015.

[19] J.-U. Lee, T. Kim, and S.-B. Leigh, "Applications of buildingintegrated coil-type ground-coupled heat exchangers-Comparison of performances of vertical and horizontal installations," Energy and Buildings, vol. 93, pp. 99-109, 2015.

[20] S. Yoon, S.-R. Lee, J. Xue, K. Zosseder, G.-H. Go, and H. Park, "Evaluation of the thermal efficiency and a cost analysis of different types of ground heat exchangers in energy piles," Energy Conversion and Management, vol. 105, pp. 393-402, 2015.

[21] D. Wang, L. Lu, W. Zhang, and P. Cui, "Numerical and analytical analysis of groundwater influence on the pile geothermal heat exchanger with cast-in spiral coils," Applied Energy, vol. 160, pp. 705-714, 2015.

[22] D. Wang, L. Lu, and P. Cui, "A novel composite-medium solution for pile geothermal heat exchangers with spiral coils," International Journal of Heat and Mass Transfer, vol. 93, pp. 760-769, 2016.

[23] S. Park, S. Lee, D. Lee, S. S. Lee, and H. Choi, "Influence of coil pitch on thermal performance of coil-type cast-in-place energy piles," Energy and Buildings, vol. 129, pp. 344-356, 2016.

[24] Q. Zhao, B. Chen, and F. Liu, "Study on the thermal performance of several types of energy pile ground heat 
exchangers: U-shaped, W-shaped and spiral-shaped," Energy and Buildings, vol. 133, pp. 335-344, 2016.

[25] J. Luo, H. Zhao, S. Gui, W. Xiang, J. Rohn, and P. Blum, "Thermo-economic analysis of four different types of ground heat exchangers in energy piles," Applied Thermal Engineering, vol. 108, pp. 11-19, 2016.

[26] A. Zarrella, G. Emmi, R. Zecchin, and M. De Carli, "An appropriate use of the thermal response test for the design of energy foundation piles with U-tube circuits," Energy and Buildings, vol. 134, pp. 259-270, 2017.

[27] M. Faizal, A. Bouazza, and R. M. Singh, "Heat transfer enhancement of geothermal energy piles," Renewable and Sustainable Energy Reviews, vol. 57, pp. 16-33, 2016.

[28] F. Delaleux, X. Py, R. Olives, and A. Dominguez, "Enhancement of geothermal borehole heat exchangers performances by improvement of bentonite grouts conductivity," Applied Thermal Engineering, vol. 33-34, pp. 92-99, 2012.

[29] C. J. R. Coccia, R. Gupta, J. Morris, and J. S. McCartney, "Municipal solid waste landfills as geothermal heat sources," Renewable and Sustainable Energy Reviews, vol. 19, pp. 463474, 2013.

[30] I. Indacoechea-Vega, P. Pascual-Muñoz, D. Castro-Fresno, and M. A. Calzada-Pérez, "Experimental characterization and performance evaluation of geothermal grouting materials subjected to heating-cooling cycles," Construction and Building Materials, vol. 98, pp. 583-592, 2015.

[31] P. Ocłoń, P. Cisek, M. Pilarczyk, and D. Taler, "Numerical simulation of heat dissipation processes in underground power cable system situated in thermal backfill and buried in a multilayered soil," Energy Conversion and Management, vol. 95, pp. 352-370, 2015.

[32] X. Li, C. Tong, L. Duanmu, and L. Liu, "Research on U-tube heat exchanger with shape-stabilized phase change backfill material," Procedia Engineering, vol. 146, pp. 640-647, 2016.

[33] M. E. Suryatriyastuti, H. Mroueh, and S. Burlon, "Understanding the temperature-induced mechanical behaviour of energy pile foundations," Renewable and Sustainable Energy Reviews, vol. 16, no. 5, pp. 3344-3354, 2012.

[34] H. Park, S.-R. Lee, S. Yoon, and J.-C. Choi, "Evaluation of thermal response and performance of PHC energy pile: field experiments and numerical simulation," Applied Energy, vol. 103, pp. 12-24, 2013.

[35] P. Hu, J. Zha, F. Lei, N. Zhu, and T. Wu, "A composite cylindrical model and its application in analysis of thermal response and performance for energy pile," Energy and Buildings, vol. 84, pp. 324-332, 2014.

[36] N. Batini, A. F. Rotta Loria, P. Conti, D. Testi, W. Grassi, and L. Laloui, "Energy and geotechnical behaviour of energy piles for different design solutions," Applied Thermal Engineering, vol. 86, pp. 199-213, 2015.

[37] R. M. Singh, A. Bouazza, and B. Wang, "Near-field ground thermal response to heating of a geothermal energy pile: observations from a field test," Soils and Foundations, vol. 55, no. 6, pp. 1412-1426, 2015.

[38] G. A. Akrouch, M. Sánchez, and J.-L. Briaud, “An experimental, analytical and numerical study on the thermal efficiency of energy piles in unsaturated soils," Computers and Geotechnics, vol. 71, pp. 207-220, 2016.

[39] T. V. Bandos, Á. Campos-Celador, L. M. López-González, and J. M. Sala-Lizarraga, "Finite cylinder-source model for energy pile heat exchangers: effect of buried depth and heat load cyclic variations," Applied Thermal Engineering, vol. 96, pp. 130-136, 2016.
[40] W. Yang, P. Lu, and Y. Chen, "Laboratory investigations of the thermal performance of an energy pile with spiral coil ground heat exchanger," Energy and Buildings, vol. 128, pp. 491-502, 2016.

[41] A. Franco, R. Moffat, M. Toledo, and P. Herrera, "Numerical sensitivity analysis of thermal response tests (TRT) in energy piles," Renewable Energy, vol. 86, pp. 985-992, 2016.

[42] D. Perić, T. V. Tran, and M. Miletic, "Effects of soil anisotropy on a soil structure interaction in a heat exchanger pile," Computers and Geotechnics, vol. 86, pp. 193-202, 2017.

[43] S. Park, D. Lee, S. Lee, A. Chauchois, and H. Choi, "Experimental and numerical analysis on thermal performance of large-diameter cast-in-place energy pile constructed in soft ground," Energy, vol. 118, pp. 297-311, 2017.

[44] W. Zhang, H. Yang, L. Fang, P. Cui, and Z. Fang, "Study on heat transfer of pile foundation ground heat exchanger with three-dimensional groundwater seepage," International Journal of Heat and Mass Transfer, vol. 105, pp. 58-66, 2017.

[45] F. Loveridge and W. Powrie, "G-functions for multiple interacting pile heat exchangers," Energy, vol. 64, pp. 747-757, 2014.

[46] A. F. Rotta Loria and L. Laloui, "The interaction factor method for energy pile groups," Computers and Geotechnics, vol. 80, pp. 121-137, 2016.

[47] Y. Cui and J. Zhu, "3D transient heat transfer numerical analysis of multiple energy piles," Energy and Buildings, vol. 134, pp. 129-142, 2017.

[48] S. Jeong, H. Lim, J. K. Lee, and J. Kim, “Thermally induced mechanical response of energy piles in axially loaded pile groups," Applied Thermal Engineering, vol. 71, no. 1, pp. 608-615, 2014.

[49] J. Fadejev, R. Simson, J. Kurnitski, J. Kesti, T. Mononen, and P. Lautso, "Geothermal heat pump plant performance in a nearly zero-energy building," Energy Procedia, vol. 96, pp. 489-502, 2016.

[50] A. Di Donna, A. F. Rotta Loria, and L. Laloui, "Numerical study of the response of a group of energy piles under different combinations of thermo-mechanical loads," Computers and Geotechnics, vol. 72, pp. 126-142, 2016.

[51] A. F. Rotta Loria, A. Vadrot, and L. Laloui, "Effect of nonlinear soil deformation on the interaction among energy piles," Computers and Geotechnics, vol. 86, pp. 9-20, 2017.

[52] R. Ramsden, T. J. Sheer, and M. D. Buttrworth, "Design and simulation of ultra-deep mine cooling systems," in Proceedings of the 7th International Mine Ventilation Congress, pp. 755-760, Krakow, Poland, 2001.

[53] S. J. Biuhm, M. Biffi, and R. B. Wilson, "Optimized cooling systems for mining at extreme depths," CIM Bulletin, vol. 93, no. 1, pp. 146-150, 2000.

[54] M.-c. He, "Application of HEMS cooling technology in deep mine heat hazard control," Mining Science and Technology, vol. 19, no. 3, pp. 269-275, 2009.

[55] G. E. Du Plessis, L. Liebenberg, and E. H. Mathews, "The use of variable speed drives for cost-effective energy savings in South African mine cooling systems," Applied Energy, vol. 111, pp. 16-27, 2013.

[56] G. E. Du Plessis, D. C. Arndt, and E. H. Mathews, "The development and integrated simulation of a variable water flow energy saving strategy for deep-mine cooling systems," Sustainable Energy Technologies and Assessments, vol. 10, pp. 71-78, 2015.

[57] D. Apel, W. Liu, and V. Bindiganavile, "Simulation of the effects of thermo insulating shotcrete on the energy consumption of ventilation and cooling systems at deep 
underground mines," in Proceedings of the Mine Planning and Equipment Selection, pp. 37-42, Dresden, Germany, October 2013.

[58] W. Chen, S. Liang, and J. Liu, "Proposed split-type vapor compression refrigerator for heat hazard control in deep mines," Applied Thermal Engineering, vol. 105, pp. 425-435, 2016.

[59] P. Guo, G. Zhu, and M. He, "HEMS technique for heat-harm control and geo-thermal utilization in deep mines," International Journal of Coal Science and Technology, vol. 1, no. 3, pp. 289-296, 2014.

[60] S. A. Ghoreishi-Madiseh, F. Hassani, and F. Abbasy, "Numerical and experimental study of geothermal heat extraction from backfilled mine stopes," Applied Thermal Engineering, vol. 90, pp. 1119-1130, 2015.

[61] E. Peralta Ramos, K. Breede, and G. Falcone, "Geothermal heat recovery from abandoned mines: a systematic review of projects implemented worldwide and a methodology for screening new projects," Environmental Earth Sciences, vol. 73, no. 11, pp. 6783-6795, 2015.

[62] P. Guo, M. He, L. Zheng, and N. Zhang, "A geothermal recycling system for cooling and heating in deep mines," Applied Thermal Engineering, vol. 116, pp. 833-839, 2017.

[63] T. Mimouni, F. Dupray, and L. Laloui, "Estimating the geothermal potential of heat-exchanger anchors on a cut-andcover tunnel,” Geothermics, vol. 51, pp. 380-387, 2014.

[64] M. Barla, A. Di Donna, and A. Perino, "Application of energy tunnels to an urban environment," Geothermics, vol. 61, pp. 104-113, 2016.

[65] C. Lee, S. Park, H.-J. Choi, I.-M. Lee, and H. Choi, "Development of energy textile to use geothermal energy in tunnels," Tunnelling and Underground Space Technology, vol. 59, pp. 105-113, 2016.

[66] P. Buhmann, C. Moormann, B. Westrich, N. Pralle, and W. Friedemann, "Tunnel geothermics-a German experience with renewable energy concepts in tunnel projects," Geomechanics for Energy and the Environment, vol. 8, pp. 1-7, 2016.

[67] J. C. López, A. L. Grindlay, and A. Peña-García, "A proposal for evaluation of energy consumption and sustainability of road tunnels: the sustainability vector," Tunnelling and Underground Space Technology, vol. 65, pp. 53-61, 2017.

[68] J. Jiang, China's Energy Policy 2012, Information Office of the State Council, Beijing, China, 2012.

[69] H. Long, Z. Qingjun, T. Puyuan, and H. Wenguang, Technologies and Applications of Geophysical Exploration in Deep Geothermal Resources in China, World Geothermal Congress, Melbourne, Australia, 2015.

[70] G. Wang, K. Li, D. Wen et al., Assessment of Geothermal Resources in China, Stanford University, Stanford, CA, USA, 2013.

[71] J. Zhu, K. Hu, X. Lu, X. Huang, K. Liu, and X. Wu, “A review of geothermal energy resources, development, and applications in China: current status and prospects," Energy, vol. 93, pp. 466-483, 2015.

[72] D. Chen and H. W. Chen, "Using the Köppen classification to quantify climate variation and change: an example for 1901-2010," Environmental Development, vol. 6, no. 1, pp. 69-79, 2013.

[73] A. Pmc, A. Cb, B. Aks, and R. Marchetti, "Worldwide dynamic predictive analysis of building performance under long-term climate change conditions," Journal of Building Engineering, vol. 42, no. 11, Article ID 103057, 2021.
[74] W. Ting, Z. Daowei, and S. Xiangjin, "Koppen's climate classification map for China," Journal of the Meteorological Sciences, vol. 40, pp. 752-760, 2020.

[75] Z. Wang, T. Zhang, M. Shao, T. Ai, and P. Zhao, "Investigation on snow-melting performance of asphalt mixtures incorporating with salt-storage aggregates," Construction and Building Materials, vol. 142, pp. 187-198, 2017.

[76] J. Wåhlin and A. Klein-Paste, "The effect of mass diffusion on the rate of chemical ice melting using aqueous solutions," Cold Regions Science and Technology, vol. 139, pp. 11-21, 2017.

[77] M. Chen, S. Wu, H. Wang, and J. Zhang, "Study of ice and snow melting process on conductive asphalt solar collector," Solar Energy Materials and Solar Cells, vol. 95, no. 12, pp. 3241-3250, 2011.

[78] Y. Lai, Y. Liu, and D. Ma, "Automatically melting snow on airport cement concrete pavement with carbon fiber grille," Cold Regions Science and Technology, vol. 103, pp. 57-62, 2014.

[79] J.-P. Won, C.-K. Kim, S.-J. Lee, J.-H. Lee, and R.-W. Kim, "Thermal characteristics of a conductive cement-based composite for a snow-melting heated pavement system," Composite Structures, vol. 118, pp. 106-111, 2014.

[80] A. D. W. Nuijten and K. V. Høyland, "Comparison of melting processes of dry uncompressed and compressed snow on heated pavements," Cold Regions Science and Technology, vol. 129, pp. 69-76, 2013.

[81] K. Liu, S. Huang, F. Wang, H. Xie, and X. Lu, "Energy consumption and utilization rate analysis of automatically snow-melting system in infrastructures by thermal simulation and melting experiments," Cold Regions Science and Technology, vol. 138, pp. 73-83, 2017.

[82] K. Liu, S. Huang, C. Jin, and H. Xie, "Prediction models of the thermal field on ice-snow melting pavement with electric heating pipes," Applied Thermal Engineering, vol. 120, 2017.

[83] P. Pan, "A review on hydronic asphalt pavement for energy harvesting and snowmelting," Renewable and Sustainable Energy Reviews, vol. 48, pp. 624-634, 2017.

[84] N. Yildirim and A. Hepbasli, "Exergetic aspects of snow melting using a geothermal heat pump system," in Proceedings of the World Geothermal Congress 2015, pp. 1-11, Melbourne, Australia, April 2015.

[85] H. Xu and Y. Tan, "Modeling and operation strategy of pavement snow melting systems utilizing low-temperature heating fluids," Energy, vol. 80, pp. 666-676, 2015.

[86] C. Han and X. Yu, "Feasibility of geothermal heat exchanger pile-based bridge deck snow melting system: a simulation based analysis," Renewable Energy, vol. 101, pp. 214-224, 2017.

[87] X. Wang, Y. Zhu, M. Zhu, Y. Zhu, H. Fan, and Y. Wang, "Thermal analysis and optimization of an ice and snow melting system using geothermy by super-long flexible heat pipes," Applied Thermal Engineering, vol. 112, pp. 1353-1363, 2014.

[88] T. R. Clyne, X. Li, M. Mo, and S. El, Dynamic and Resilient Modulus of Mn/DOT Asphalt Mixtures, University of Minnesota, Minneapolis, MN, USA, 2003.

[89] B. Barra, L. Momm, Y. Guerrero, H. A. Al-Qureshi, A. Mikowski, and R. Michels, "Temperature implications on rheological-mechanical behavior and design of high modulus dense asphalt mix," Construction and Building Materials, vol. 125, pp. 135-144, 2016.

[90] M. Kim, L. N. Mohammad, P. Phaltane, and M. A. Elseifi, "Density and SCB measured fracture resistance of temperature segregated asphalt mixtures," International Journal of Pavement Research and Technology, vol. 10, no. 2, pp. 112-121, 2017. 
[91] M. S. Sakhaeifar, Y. Richard Kim, and B. E. Garcia Montano, "Individual temperature based models for nondestructive evaluation of complex moduli in asphalt concrete," Construction and Building Materials, vol. 137, pp. 117-127, 2017.

[92] M. Ryms, H. Denda, and P. Jaskuła, "Thermal stabilization and permanent deformation resistance of LWA/PCM-modified asphalt road surfaces," Construction and Building Materials, vol. 142, pp. 328-341, 2017.

[93] H. Jahanbakhsh, M. Karimi, F. Moghadas Nejad, and B. Jahangiri, "Viscoelastic-based approach to evaluate low temperature performance of asphalt binders," Construction and Building Materials, vol. 128, pp. 384-398, 2016.

[94] R. Zhang, H. Wang, J. Gao, Z. You, and X. Yang, "High temperature performance of SBS modified bio-asphalt," Construction and Building Materials, vol. 144, pp. 99-105, 2017. 